\title{
Human Pulmonary Alveolar Proteinosis Associated with a Defect in GM-CSF/IL-3/IL-5 Receptor Common $\beta$ Chain Expression
}

\author{
Uta Dirksen, ${ }^{*}$ Ryuichi Nishinakamura, ${ }^{\S}$ Peter Groneck,, Uwe Hattenhorst, ${ }^{*}$ Lawrence Nogee, ${ }^{\mathbb{}}$ Richard Murray,§ \\ and Stefan Burdach ${ }^{\star}$ \\ *Department of Pediatrics, Children’s Hospital Medical Center and ${ }^{\ddagger}$ BioMedical Research Center (BMFZ), Heinrich Heine University, \\ D-40225 Düsseldorf, Germany; ${ }^{\S}$ DNAX Research Institute of Molecular and Cellular Biology, Palo Alto, California 94304; ${ }^{D}$ Division of \\ Neonatology, Children's Hospital, D-50735 Cologne, Germany; and "Eudowood Neonatal Pulmonary Division, Johns Hopkins \\ University School of Medicine, Baltimore, Maryland 21287-3200
}

\begin{abstract}
Pulmonary alveolar proteinosis (PAP) is a heterogenous disorder of genetic or acquired etiologies. In some cases congenital PAP is associated with hereditary surfactant protein (SP)-B deficiency. To date, the molecular defect in the majority of patients with PAP has not been identified. In mice, PAP has been generated by targeted deletion of the genes for either the GM-CSF/IL-3/IL-5 receptor common $\beta$ chain $(\beta c)$ or GM-CSF. Here, we describe an expression defect of $\beta c$ in three of seven pediatric patients with PAP and in one patient with severe lung disease suspected to be PAP. The patients failed to express normal levels of $\beta c$ as shown by flow cytometry. Strikingly reduced or absent function of $\beta c$ was demonstrated by ligand binding studies and progenitor clonogenic assays. Analysis of $\beta \mathrm{c}$ DNA revealed a point mutation from proline to threonine at codon 602 in one patient. Our findings provide evidence that a defect in the expression of a hematopoietic cytokine receptor is associated with human PAP. (J. Clin. Invest. 1997. 100:2211-2217.) Key words: pulmonary alveolar proteinosis • GM-CSF/IL-3/IL-5 receptor • common $\beta$ chain • alveolar macrophages - surfactant
\end{abstract}

\section{Introduction}

Pulmonary alveolar proteinosis $(\mathrm{PAP})^{1}$ is a rare cause of respiratory failure. PAP is a heterogenous disorder of acquired or genetic etiology. Nevertheless the cause of most cases is unknown. PAP is characterized by occurrence of severe respiratory distress and rapid progression to death. Some cases of congenital PAP have been described to be associated with deficiency of surfactant protein (SP)-B as a result of a frameshift

Address correspondence to Stefan Burdach, M.D., Ph.D., University Medical Center, Department of Pediatrics, Moorenstr. 5, D-40225 Düsseldorf, Germany. Phone: 49-211-81-16186; FAX: 49-211-8116191; E-mail: burdach@uni.duesseldorf.de

Received for publication 6 November 1996 and accepted in revised form 29 August 1997.

1. Abbreviations used in this paper: $\mathrm{BAL}$, bronchoalveolar lavage; EPO, erythropoietin; OLB, open lung biopsy; PAP, pulmonary alveolar proteinosis; PAS, periodic acid Schiff; rh, recombinant human; SCF, stem cell factor; SP, surfactant protein.

J. Clin. Invest.

(C) The American Society for Clinical Investigation, Inc. 0021-9738/97/11/2211/07 \$2.00

Volume 100, Number 9, November 1997, 2211-2217

http://www.jci.org mutation (121ins2) $(1,2)$ accompanied by qualitative and quantitative abnormalities of SP-A and -C (1) in the majority of these cases (3-5). There are also rare cases of congenital PAP that have been observed with prolonged survival (6). To date, genetic analysis has been reported only in a minority of published patients with $\operatorname{PAP}(3,4,7,8)$.

In mice, alveolar proteinosis is associated with a deletion of the GM-CSF gene $(9,10)$ or with a deficiency of the GM-CSF/ IL-3/IL-5 receptor common $\beta$ ( $\beta c$ ) chain (11). The lung pathology in both types of mutant mice shows significant similarities to human alveolar proteinosis.

In this report we describe seven infants with PAP (patients A, C, D, E, F, G, and H) who had no SP-B deficiency and one patient with severe lung disease suspected to be PAP (patient B). All patients developed respiratory insufficiency within 17 mo after birth requiring mechanical ventilation or extracorporal oxygenation. Molecular and cellular analysis of the patients' mononuclear cells revealed the $\beta c$ receptor deficiency in four of the eight patients, suggesting that alveolar proteinosis in these infants may be linked to the hematopoietic system.

\section{Methods}

Case reports. The case reports of all patients and diagnostic criteria for PAP are summarized in Table I. The diagnosis of PAP was confirmed by histological analysis of open lung biopsy (OLB) material and cytopathologic analysis of bronchoalveolar lavage (BAL). OLB was performed in patients A, C, E, F, and G. The pathological analysis showed typical signs of PAP: the alveolar space was filled with an amorphous, periodic acid Schiff (PAS)-positive, proteinaceous material containing enlarged foamy macrophages (data not shown). In patients A, C, E, F, and $\mathrm{H}$ cytospins of the BAL were analyzed with cytopathological techniques. The samples showed the PAP-typical accumulation of amorphous PAS-positive material and enlarged alveolar macrophages with signs of vacuolization of their cytoplasm (data not shown). In patient $\mathrm{D}, \mathrm{G}$, and $\mathrm{H}$ samples, no cytopathological diagnosis was available. However, the samples were analyzed for SP content (see below). Patient B denied the performance of an OLB or BAL. In this case the diagnosis was suspected by the finding of large amounts of proteinaceous, PAS-positive material in his tracheal aspirate (data not shown).

Characteristics of control patients. The clinical data of the control patients are listed in Table II. All patients suffered from respiratory distress. In neither of the patients was there evidence of alveolar proteinosis. In patients 1, 3, 4, and 6 PAP was excluded by cytopathology and/or histology. In patients 2, 5, and 7 PAP was not suggested.

SP quantification. For the diagnosis of possible hereditary SP-B deficiency, quantitative levels of SP-A and -B were determined in BAL fluid or pooled tracheal aspirate by ELISA assay using the monoclonal antibodies PE10 and 8B5E as described $(1,4,12)$.

GM-CSF protein quantification. PBMCs were cultured in RPMI 1640 containing $10 \%$ AB-serum $\left(10^{6}\right.$ cells $\left./ \mathrm{ml}\right)$ in the presence or absence of IL-2 (100 U/ml) generously provided by Eurocetus/Chiron 
Table I. Clinical Presentation of the Patients and Investigations

\begin{tabular}{lclll}
\hline Patient & Age of $\beta$ c analysis & \multicolumn{1}{c}{ Age and diagnosis } & \multicolumn{1}{c}{ Therapy } & \\
\hline & $m o$ & & & \\
A & 20 & Neonatal, OLB, BAL & Ther. BAL, Surf, Ventil & $\mathrm{O}_{2}$-dependent \\
B & 264 & Neonatal & Ventil & $\mathrm{O}_{2}$-dependent \\
C & 13 & Neonatal, BAL & Ther. BAL, Ventil & $\mathrm{O}_{2}$-dependent \\
D & 4 & 3 mo, BAL, OLB & ECMO, Ther. BAL, Lung Tx & Ventil \\
E & 24 & 17 mo, BAL & Ventil & Died \\
F & 69 & 3 mo, BAL, OLB & Ther. BAL, Surf, Ventil & Doing well \\
G & 8 & 2 mo, BAL, OLB & Ventil, Lung Tx & $\mathrm{O}_{2}$-dependent \\
H & 73 & 1 mo, BAL & Ventil & \\
\end{tabular}

Summary of patient data. Ther., Therapeutic; Surf, surfactant; Ventil, mechanical ventilation; ECMO, extracorporal membrane oxygenation; Lung $T x$, bilateral lung transplantation.

(Ratingen, Germany). Before culture, cells were activated by incubation of the cell pellet with soluble CD3 antibody (BMA 030; $0.1 \mu \mathrm{g} /$ $\mathrm{ml}$; Behring, Marburg, Germany) for $20 \mathrm{~min}$ at $4^{\circ} \mathrm{C}$. The culture periods were chosen as described (13). Culture supernatants or plasma were assessed for GM-CSF concentration by ELISA (DPC Biermann, Bad Nauheim, Germany).

Flow cytometry analysis. $\beta c(C D w 131)$ monoclonal antibody (S-16), the GM-CSF receptor $\alpha$ chain (CD116) mAb (S-20, and S-50, data not shown), the IL-3 receptor $\alpha$ chain (CDw123) mAb (S-12) (Santa Cruz Biotechnology, Santa Cruz, CA) were used for immunofluorescence cell staining. The antibodies recognize the extracellular domain of $\beta c$, GM-CSF-R $\alpha$, and IL-3-R $\alpha$, respectively. Indirect cell staining with a fluorochrome-conjugated isotype-matched control antibody (Dianova, Hamburg, Germany) was performed according to standard laboratory procedure as previously described (14). Briefly, cells were incubated with the first antibody 15-30 min at room temperature, washed twice with PBS, and stained for $30 \mathrm{~min}$ with the fluorochrome-conjugated second antibody. After washing with PBS both indirect and direct stained samples were incubated with the FACS $^{\circledR}$ lysing solution according to the manufacturer's procedure (Becton Dickinson, Heidelberg, Germany). Fluorescence intensity is expressed as percent positive cells. Analysis was performed by FACScan ${ }^{\circledR}$ using the Lysis II program (Becton Dickinson) according to the manufacturer's guidelines. We performed kinetic studies in healthy individuals to measure the stability of the GM-CSF-R $\alpha$ and $\beta c$ expression. Two samples were stored at $4^{\circ} \mathrm{C}$ for $7 \mathrm{~d}$ and three samples were stored at room temperature for $3 \mathrm{~d}$. The samples were analyzed daily up to $7 \mathrm{~d}$ (Table III). We found a stable receptor expression at all times. In patients $\mathrm{A}$ and $\mathrm{B}, \beta \mathrm{c}$ expression was analyzed kinetically (10 min, $1 \mathrm{~h}, 2 \mathrm{~h}$, and $4 \mathrm{~h}$ after venipuncture). $\beta \mathrm{c}$ was not detectable at any time (see Table VI).

Ligand binding studies. For binding assays, $10^{6}-10^{7}$ whole blood cells were incubated with $10 \mathrm{mM} \mathrm{NaPO}_{4}, 150 \mathrm{mM} \mathrm{NaCl}, \mathrm{pH} 3$, for 2-3 min, diluted to $60 \mathrm{ml}$ with $10 \mathrm{mM} \mathrm{NaPO}_{4}, 150 \mathrm{mM} \mathrm{NaCl}$, $\mathrm{pH}$ 7, centrifuged, and resuspended in PBS with $1 \%$ BSA. Binding was performed at $23^{\circ} \mathrm{C}$ for $2 \mathrm{~h}$. Curves were established by incubating the cells with 10-2,500 pmol/liter of ${ }^{125} \mathrm{I}$ hGM-CSF (Amersham, Braunschweig, Germany) in a total volume of $400 \mu \mathrm{l}$ PBS. 1\% BSA and $0.02 \%$ sodium azide were added to avoid internalization and degradation of the radiolabeled GM-CSF by cells. Cells were incubated in the absence or presence of an excess (150-fold) of unlabeled GMCSF (Leucomax; Sandoz, Nürnberg, Germany). Separation between bound and free radioactivity was achieved by centrifugation through a paraffin-oil layer (Merck, Darmstadt, Germany). Determination of the radioactivity in the cell pellets or in the cell-free supernatants was performed in a $\gamma$-counter. Specific binding was defined as the amount of binding blocked by competition with a 150 -fold excess of cold GMCSF. Calculation of binding kinetics was performed according to the manufacturer's description. To exclude nonspecific effects, the analysis of each patient's cells was combined with the analysis of a control.

Progenitor clonogenic assays. PBMCs were cultured at a concentration of $1.5 \times 10^{5}$ cells $/ \mathrm{ml}$ culture medium in 24-well plates at $5 \%$ $\mathrm{O}_{2}, 37^{\circ} \mathrm{C}$ humidified atmosphere. The culture medium consisted of $30 \%$ FCS (Sigma, Deisenhofen, Germany), 1\% 2-mercaptoethanol (Sigma), 1\% penicillin-streptomycin solution (Gibco, Eggenstein, Germany), 1\% L-glutamine, 10\% bovine serum albumin (Behring) with sodium bicarbonate, $0.5 \mathrm{U}$ recombinant human (rh) erythropoietin (EPO), 40\% methylcellulose, and 500-5,000 U of rhIL-3 (Behr-

Table II. Clinical Presentation of the Control Patients and Investigations

\begin{tabular}{|c|c|c|c|c|}
\hline Control patient & Age of $\beta c$ analysis & Diagnosis & Therapy & Outcome \\
\hline & mo & & & \\
\hline 1 & 0.5 & RDS, BAL, p.m. OLB & Surf, Ventil & Died \\
\hline 2 & 1 & RDS & $\mathrm{O}_{2}$ & Doing well \\
\hline 3 & 6 & SCID, ARDS, BAL & Ventil & Ventil \\
\hline 4 & 15 & PCP, BAL & Ventil & Doing well \\
\hline 5 & 15 & Aspiration, ARDS & Ventil & Ventil \\
\hline 6 & 180 & RLD, BAL & Ambroxol, salbutamol & Doing well \\
\hline 7 & 130 & RLD & Salbutamol & Acceptable condition \\
\hline
\end{tabular}

Summary of control patient data. Surf, Surfactant; Ventil, mechanical ventilation; p.m., postmortem; $P C P$, pneumocystis carinii pneumonia; $R L D$, restrictive lung disease; $R D S$, respiratory distress syndrome; $A R D S$, adult respiratory distress syndrome. 
Table III. Kinetic Study of $\beta c$ and GM-CSF-R $\alpha(R \alpha)$ Expression

\begin{tabular}{|c|c|c|c|c|c|c|c|c|}
\hline \multirow[b]{2}{*}{$4^{\circ} \mathrm{C}$} & \multicolumn{2}{|c|}{$24 \mathrm{~h}$} & \multicolumn{2}{|c|}{$72 \mathrm{~h}$} & \multicolumn{2}{|c|}{$96 \mathrm{~h}$} & \multicolumn{2}{|c|}{$144 \mathrm{~h}$} \\
\hline & $\beta c$ & $\mathrm{R} \alpha$ & $\beta c$ & $\mathrm{R} \alpha$ & $\beta c$ & $\mathrm{R} \alpha$ & $\beta c$ & $\mathrm{R} \alpha$ \\
\hline \multirow[t]{2}{*}{$n=2$} & $98 \pm 0.5 \%$ & $93 \pm 6 \%$ & $87 \pm 5 \%$ & $87 \pm 1 \%$ & $80 \pm 13 \%$ & $91 \pm 4 \%$ & $86 \pm 0.5 \%$ & $84 \pm 0.5 \%$ \\
\hline & \multicolumn{2}{|c|}{$24 \mathrm{~h}$} & \multicolumn{2}{|c|}{$48 \mathrm{~h}$} & \multicolumn{2}{|c|}{$72 \mathrm{~h}$} & & \\
\hline RT & $\beta c$ & $\mathrm{R} \alpha$ & $\beta c$ & $\mathrm{R} \alpha$ & $\beta c$ & $\mathrm{R} \alpha$ & & \\
\hline$n=3$ & $95 \pm 4 \%$ & $94 \pm 3 \%$ & $95 \pm 4 \%$ & $97 \pm 3$ & $98 \pm 1 \%$ & $95 \pm 1$ & & \\
\hline
\end{tabular}

Kinetic studies were performed in healthy individuals to measure the stability of the $\beta \mathrm{c}$ and GM-CSF R $\alpha$ expression. Two samples were stored at $4{ }^{\circ} \mathrm{C}$ for $7 \mathrm{~d}$ and three samples were stored at room temperature $(R T)$ for $3 \mathrm{~d}$. The samples were analyzed daily up to $7 \mathrm{~d}$.

ing), rhGM-CSF (Leucomax; Sandoz, Nürnberg, Germany), rhGCSF (Neupogen; Amgen/Roche, München, Germany), 500 U rhIL-6 (Laboserv, Giessen, Germany), and $500 \mathrm{U}$ rh stem cell factor (SCF) (Dianova). After $14 \mathrm{~d}$ of culture the colonies were analyzed by inverse microscopy. Each value represents the mean \pm standard error of triplicate determination. The results were analyzed by Student's $t$ test.

RNA analysis. Total cellular RNA was isolated from patient's and control's mononuclear cells with the RNAzol extraction kit (WakChemie, Bad Homburg, Germany). $1 \mu \mathrm{g}$ of total RNA was reverse transcribed according to standard procedure using first-strand cDNA synthesis kit (Pharmacia, Uppsala, Sweden). The resulting samples of cDNA were amplified by PCR. The following primers generating overlapping fragments were used (kindly provided by Carol Stocking, Hamburg): $\mathrm{NH}_{2}$ terminus, 5'-TGACCAGGGAGATGGTGCTG-3' and 5'-GTTTCTCTGCCCTCCTTGGGGC-3'; middle, 5'-CCCACGGCCAATACATCGTC and 5'-TCTCCACTTCCACGGCCTGT3'; and $\mathrm{COOH}$ terminus, 5'-GGTGCAACTGGTCCCTCTGG-3' and 5'-AAGGTCAGGCGGGAGGGAAG-3'. 35 cycles were performed and each consisted of denaturation at $94^{\circ} \mathrm{C}$ for $30 \mathrm{~s}$, annealing at $64^{\circ} \mathrm{C}$ for $30 \mathrm{~s}$, and elongation at $72^{\circ} \mathrm{C}$ for $60 \mathrm{~s}$. As an internal control, human $\beta$-actin was coamplified under identical PCR conditions (14). The amplified fragments were cloned in the $\mathrm{pCR}^{\mathrm{TM}} \mathrm{II}$ vector with the TA cloning kit (Invitrogen, San Diego, CA). 8-10 $\mu \mathrm{g}$ of plasmid DNA from independent clones containing the cDNA insert was denatured and sequenced. Sequencing was performed according to standard procedures using the AutoRead sequencing kit (Pharmacia) and additional sequencing primers: $\mathrm{COOH}$ terminus, $5^{\prime}$-TGGGGCCAGAGCA; middle terminus, 5'-TGTCGGCCTTCAC; and $\mathrm{NH}_{2}$ terminus, 5'-TGCAGCAAGTGGGCGA. Sanger chain termination reactions were analyzed with an A.L.F. DNA sequencer (Pharmacia). To exclude polymorphisms in the $\beta c$ locus, we analyzed 20 randomly selected healthy controls.

Protein structure analysis. Protein structure analyses were performed using the PC/Gene program (IntelliGenetics, Inc./Genofi SA., Geneva, Switzerland).

Statistics. Results are expressed as mean \pm standard error of the mean unless otherwise indicated. For statistical analysis the Student's $t$ test was used. Results were considered significant at $P<0.05$.

\section{Results}

To exclude a hereditary SP-B deficiency as an underlying cause for the pulmonary disease BAL and pooled tracheal aspirate samples of each patient were analyzed for SPs. SP-B as assessed by ELISA was present in ample amounts in all patients studied. In patients D, E, and G, BAL SP was not quantified, but SP-B was detected by Western analysis (Table IV). SP-A was analyzed as an internal control to ensure that the specimens were not overdiluted. SP-A was detected in all samples (Table IV).

We analyzed the GM-CSF protein production and the expression of the GM-CSF/IL-3/IL-5 receptor common $\beta$ chain $(\beta c)$ to determine if the molecular basis for the disease in these patients was comparable to the gene deleted mice.

GM-CSF protein was measured in culture supernatants of the patients' PBMCs and/or plasma. The amount of GM-CSF was normal in the patients' samples when compared with agematched controls (data not shown).

The expression of the $\beta c$ chain and the private $\alpha$ chains of the IL-3 or GM-CSF receptors (IL-3-R $\alpha$, GM-CSF-R $\alpha$ ) was analyzed by flow cytometry. All analyses were done with whole blood. GM-CSF-R $\alpha$ and IL-3-R $\alpha$ were readily detected in all analyzed patients. Patients $\mathrm{A}, \mathrm{B}, \mathrm{C}$, and $\mathrm{H}$ failed to express $\beta c$. In contrast, patients $\mathrm{D}, \mathrm{E}, \mathrm{F}$, and $\mathrm{G}$ clearly expressed $\beta c$ when compared with age-matched healthy controls and to control patients' cells (Table V).

Table IV. Exclusion of Hereditary SP-B Deficiency

\begin{tabular}{lrc}
\hline & BAL & TA \\
\hline Patient A & & \\
SP-B $(\mathrm{ng} / \mathrm{ml})$ & 5130 & 3425 \\
SP-A $(\mu \mathrm{g} / \mathrm{ml})$ & 141 & 0.1 \\
Patient B & & ND \\
SP-B $(\mathrm{ng} / \mathrm{ml})$ & ND & ND \\
SP-A $(\mu \mathrm{g} / \mathrm{ml})$ & ND & \\
Patient C & & ND \\
SP-B $(\mathrm{ng} / \mathrm{ml})$ & 2700 & ND \\
SP-A $(\mu \mathrm{g} / \mathrm{ml})$ & ND & 4300 \\
Patient F & & 1600 \\
SP-B $(\mathrm{ng} / \mathrm{ml})$ & 900 & \\
SP-A $(\mu \mathrm{g} / \mathrm{ml})$ & 65 & 4000 \\
Patient H & & 340 \\
SP-B $(\mathrm{ng} / \mathrm{ml})$ & 3210 & \\
SP-A $(\mu \mathrm{g} / \mathrm{ml})$ & 450 &
\end{tabular}

Quantitative analysis of patient SP content in BAL and tracheal aspirate $(T A)$. Patients produced high amounts of SP-B and -A in comparison to controls $(n=20)$ : SP-B, $748 \pm 85 \mathrm{ng} / \mathrm{ml}$; SP-A, $148 \pm 31 \mu \mathrm{g} / \mathrm{ml}$. These controls have been described by Kramer et al. (12). ND, Not determined. In patients D, E, and G, SP was not quantitated, but SP-B was detected by Western analysis. 
Table V. Flow Cytometry Analysis in Children with PAP

\begin{tabular}{lccc}
\hline & $\beta c$ & GM-CSF-R $\alpha$ & IL-3-R $\alpha$ \\
\hline Patient A & $<1 \% *$ & $90 \%$ & $80 \%$ \\
Patient B & $<1 \% *$ & $90 \%$ & $92 \%$ \\
Patient C & $<1 \% *$ & $20 \%$ & $30 \%$ \\
Patient D & $51 \%$ & $64 \%$ & $90 \%$ \\
Patient E & $66 \%$ & $83 \%$ & $81 \%$ \\
Patient F & $89 \%$ & $88 \%$ & $90 \%$ \\
Patient G & $80 \%$ & $89 \%$ & $89 \%$ \\
Patient H & $<1 \%$ & $87 \%$ & $88 \%$ \\
Control patient 1 & $99 \%$ & $99 \%$ & $97 \%$ \\
Control patient 2 & $98 \%$ & $96 \%$ & $95 \%$ \\
Control patient 3 & $99 \%$ & $99 \%$ & $98 \%$ \\
Control patient 4 & $98 \%$ & $97 \%$ & $99 \%$ \\
Control patient 5 & $82 \%$ & $89 \%$ & $87 \%$ \\
Control patient 6 & $98 \%$ & $88 \%$ & $99 \%$ \\
Control patient 7 & $89 \%$ & $86 \%$ & $79 \%$ \\
Control 1 & $85 \%$ & $88 \%$ & $92 \%$ \\
Control 2 & $86 \%$ & $90 \%$ & $85 \%$ \\
Control 3 & $83 \%$ & $88 \%$ & $85 \%$ \\
\end{tabular}

Flow cytometry analysis from seven patients with PAP, one patient with severe lung disease suspected to be PAP (B), seven children (control patients 1-7) with chronic lung diseases different from PAP, and three age-matched controls. ${ }^{*} P<0.05$ in comparison to controls.

Kinetic studies were performed in healthy individuals to measure the stability of the GM-CSF-R $\alpha$ and $\beta c$ expression. Two samples were stored at $4^{\circ} \mathrm{C}$ for $7 \mathrm{~d}$ and three samples were stored at room temperature for $3 \mathrm{~d}$. The samples were analyzed daily up to $7 \mathrm{~d}$. We found a stable receptor expression at all times (Table III). In patients A and B, $\beta c$ expression was analyzed kinetically (10 min, $1 \mathrm{~h}, 2 \mathrm{~h}$, and $4 \mathrm{~h}$ after venipuncture). $\beta \mathrm{c}$ was not detectable at any time (Table VI).

Fig. 1 depicts examples of the flow cytometry analysis in the first two patients with PAP and one age-matched control. GM-CSF-R $\alpha$ was found in patient A (Fig. $1 B$ ) and patient B (Fig. $1 D$ ). GM-CSF-R $\alpha($ Fig. $1 F$ ) as well as $\beta c($ Fig. $1 E$ ) were clearly expressed on age-matched control cells. However, both patients' cells failed to express $\beta \mathrm{c}$ on normal levels (Fig. 1, $A$ and $B$ ).

To independently verify the deficiency of $\beta \mathrm{c}$ on the cell surface, binding assays were performed in the $\beta c$-deficient patients $\mathrm{A}, \mathrm{B}, \mathrm{C}$, and $\mathrm{H} .{ }^{125} \mathrm{I}-\mathrm{GM}-\mathrm{CSF}$ binding revealed only lowaffinity or significantly reduced high-affinity binding with a $K_{\mathrm{d}}$ of $3.3 \mathrm{nM}$ in patient $\mathrm{A}, 1.8 \mathrm{nM}$ in patient $\mathrm{B}, 1.7 \mathrm{nM}$ in patient $\mathrm{C}$, and $1.7 \mathrm{nM}$ in patient $\mathrm{H}$, indicating the expression of the GM-CSF-R $\alpha$ chain only. The age-matched control showed the

Table VI. Kinetics of $\beta c$ Expression in Two PAP Patients

\begin{tabular}{lcccc}
\hline Patient & $10 \mathrm{~min}$ & $1 \mathrm{~h}$ & $2 \mathrm{~h}$ & $3 \mathrm{~h}$ \\
\hline $\mathrm{A}$ & $<1 \%$ & $<1 \%$ & $<1 \%$ & $<1 \%$ \\
$\mathrm{~B}$ & $<1 \%$ & $<1 \%$ & $<1 \%$ & $<1 \%$
\end{tabular}

Kinetics of $\beta c$ expression in patients A and B 10 min, 1 h, $2 \mathrm{~h}$, and $4 \mathrm{~h}$ after venipuncture. $\beta \mathrm{c}$ was not detectable at any time.
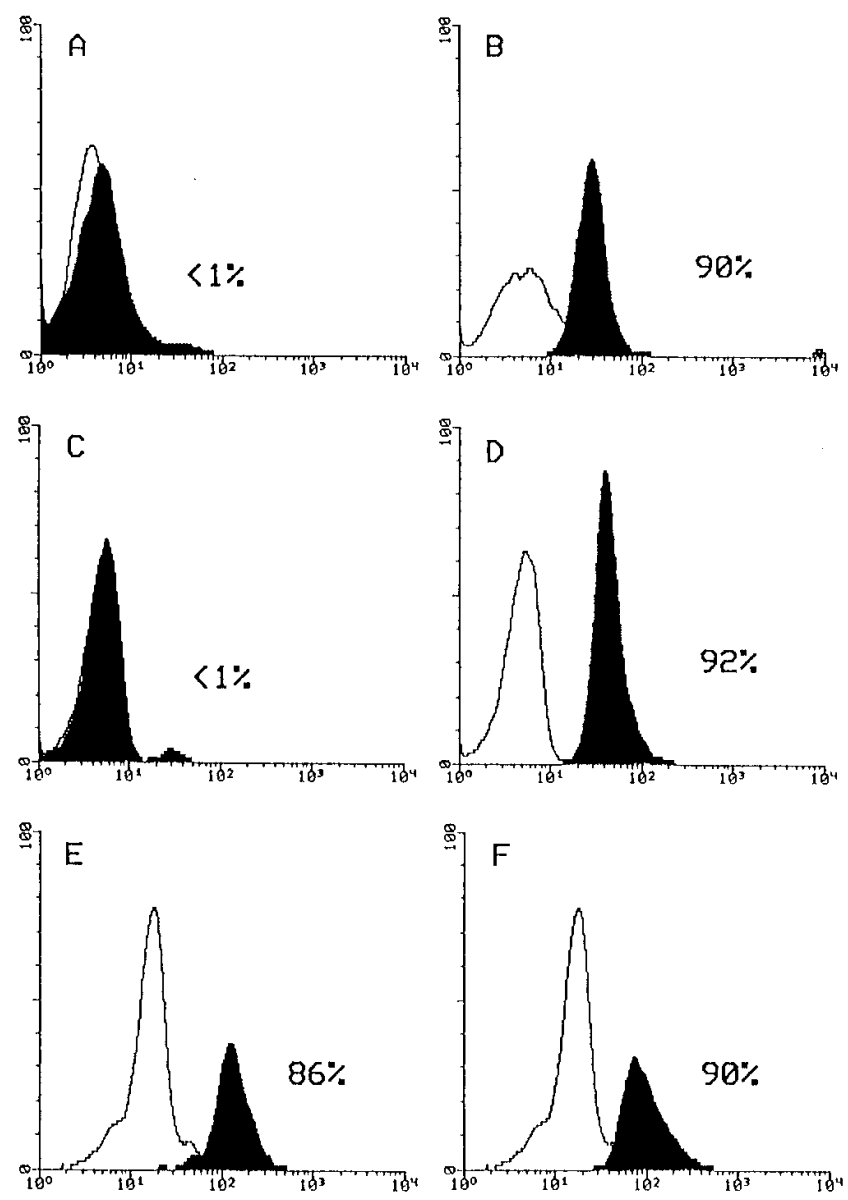

Figure 1. Flow cytometry analysis for the expression of the $\beta \mathrm{c}$ (left) and the GM-CSF-R $\alpha$ chain (right). $A$ and $B$ represent the staining of cells from patient A, $C$ and $D$ are from case patient B, and $E$ and $F$ are from healthy, age-matched controls. Shaded areas represent specific staining.

normal pattern of exclusively high-affinity binding with a $K_{\mathrm{d}}$ of $72-80 \mathrm{pM}$, indicating the expression of both GM-CSF-R $\alpha$ and $\beta c$ (Fig. 2).

Hematopoietic progenitor clonogenic assays were performed to examine the response of the $\beta c$-deficient mononuclear cells to cytokines requiring the $\beta \mathrm{c}$ receptor and $\beta c$-independent cytokines. Cells from all $\beta \mathrm{c}$-deficient patients did not respond to $\beta \mathrm{c}$-dependent cytokines such as rhGM-CSF and rhIL-3 even at high cytokine concentrations. Thus, $\beta c$ is required for GM-CSF or IL-3 signal transduction in humans. This was confirmed by normal growth of multilineage colonies in response to stimuli that act independently of receptors containing $\beta c$, such as rhG-CSF or rhIL-6/rhSCF (Table VII).

Next, we assessed the $\beta \mathrm{c}$ mRNA to investigate the underlying cause of the absence of $\beta c$ expression. RNA was prepared from patient and control PBMCs. Subsequently, we performed RT-PCR using $\beta c$-specific primers which divided the gene into three overlapping fragments. The $\beta c$ cDNA was detectable by RT-PCR (data not shown). PCR products of six independent PCR reactions of patient RNA were cloned and sequenced for possible mutations in the coding region of the $\beta c$ gene. Sequencing of patient A $\beta \mathrm{c}$ cDNA exons (AC M59941 bases: 17- 


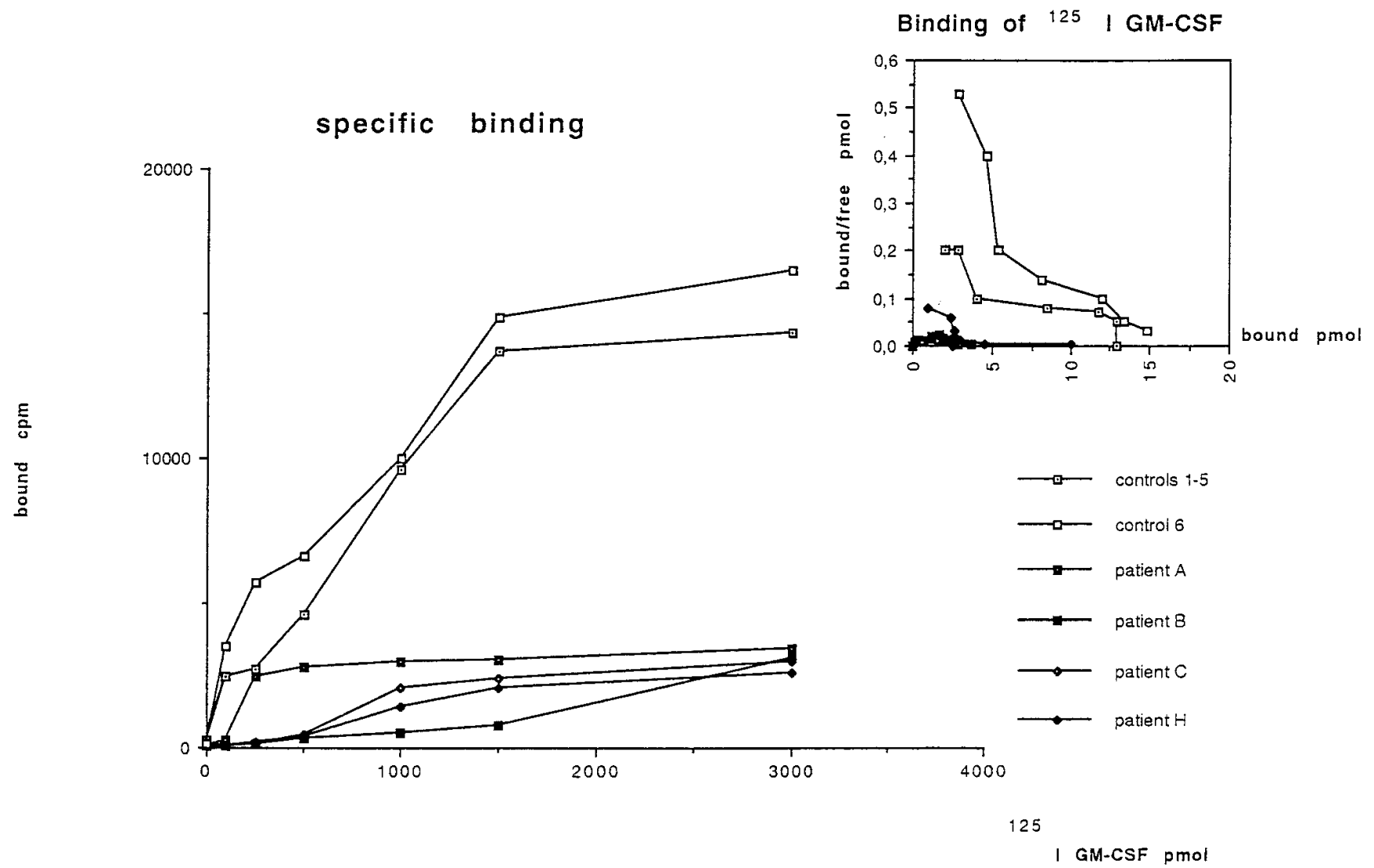

Figure 2. Scatchard analysis and binding curves (inset) of specific binding of ${ }^{125} \mathrm{I}-\mathrm{GM}$-CSF to cells of $\beta$ c-deficient patients and controls.

2784) (15) revealed a transversion from $\mathrm{C}$ to $\mathrm{A}$ at position 1835 in all clones. This point mutation results in an exchange of codon 602 from proline to threonine (Fig. 3). Otherwise, the patient's $\beta c$ cDNA did not differ from the wild-type $\beta c$ sequence. The sequences of 20 healthy controls showed no polymorphism in codon 602 (data not shown). Protein-structure analyses comparing the mutant and the wild-type $\beta c$ protein revealed changes in the hydrophobicity and the bend of the polypeptide yielding to an alteration of the $\alpha$-helical and $\beta$-sheet structure of the protein (data not shown).

\section{Discussion}

The diagnosis of PAP is based on typical histology showing the accumulation of proteinaceous material in the lung. PAP is a morphologic syndrome with variable clinical course and heterogenous etiology. Causes of PAP comprise aberrant response to infection, underlying diseases such as myelogenous leukemia $(15,16)$ or lysinuric protein intolerance, disturbed surfactant metabolism, or unusual injury response to inhaled agents, e.g., silica or aluminum (6). Occurrence in infancy suggests a ge-

Table VII. Colony-forming Unit Assay from Peripheral Blood

\begin{tabular}{|c|c|c|c|c|c|}
\hline Stimulation & EPO & $\mathrm{EPO} / \mathrm{GM}-\mathrm{CSF}$ & $\mathrm{EPO} / \mathrm{IL}-3$ & $\mathrm{EPO} / \mathrm{G}-\mathrm{CSF}$ & EPO/IL-6/SCF \\
\hline Patient A (experiment 1$)$ & $2 \pm 2$ & $4 \pm 2 *$ & $6 \pm 1 *$ & $95 \pm 10$ & ND \\
\hline Patient A (experiment 2) & $1 \pm 1$ & $0 \pm 0 *$ & $1 \pm 1 *$ & $69 \pm 4$ & $89 \pm 12$ \\
\hline Patient B & $0 \pm 1$ & $1 \pm 1 *$ & $1 \pm 1 *$ & $142 \pm 50$ & $102 \pm 62$ \\
\hline Patient C & $3 \pm 1$ & $2 \pm 1 *$ & $0 \pm 0 *$ & $67 \pm 12$ & $98 \pm 6$ \\
\hline Patient $\mathrm{H}$ & $4 \pm 2$ & $1 \pm 1^{*}$ & ND & $45 \pm 4$ & $48 \pm 8$ \\
\hline Patient E & $23 \pm 5$ & $54 \pm 6$ & $32 \pm 8$ & $65 \pm 9$ & $55 \pm 4$ \\
\hline Patient $\mathrm{G}$ & $10 \pm 5$ & $89 \pm 10$ & $76 \pm 4$ & $77 \pm 19$ & $83 \pm 13$ \\
\hline Control 1 & $2 \pm 2$ & $71 \pm 10$ & $35 \pm 4$ & $109 \pm 6$ & ND \\
\hline Control 2 & $3 \pm 1$ & $64 \pm 7$ & $56 \pm 3$ & $91 \pm 7$ & ND \\
\hline Control 3 & $0 \pm 0$ & $31 \pm 2$ & $46 \pm 1$ & $53 \pm 8$ & $97 \pm 02$ \\
\hline
\end{tabular}

Granulocyte/macrophage colony-forming unit assay from cells of $\beta c$-deficient patients $\mathrm{A}, \mathrm{B}, \mathrm{C}$, and $\mathrm{H}$, from $\beta \mathrm{c}$-nondeficient patients E and $\mathrm{G}$, and from healthy controls. Each value represents the mean of triplicate determinations. ${ }^{*} P<0.05$ in comparison to controls. 


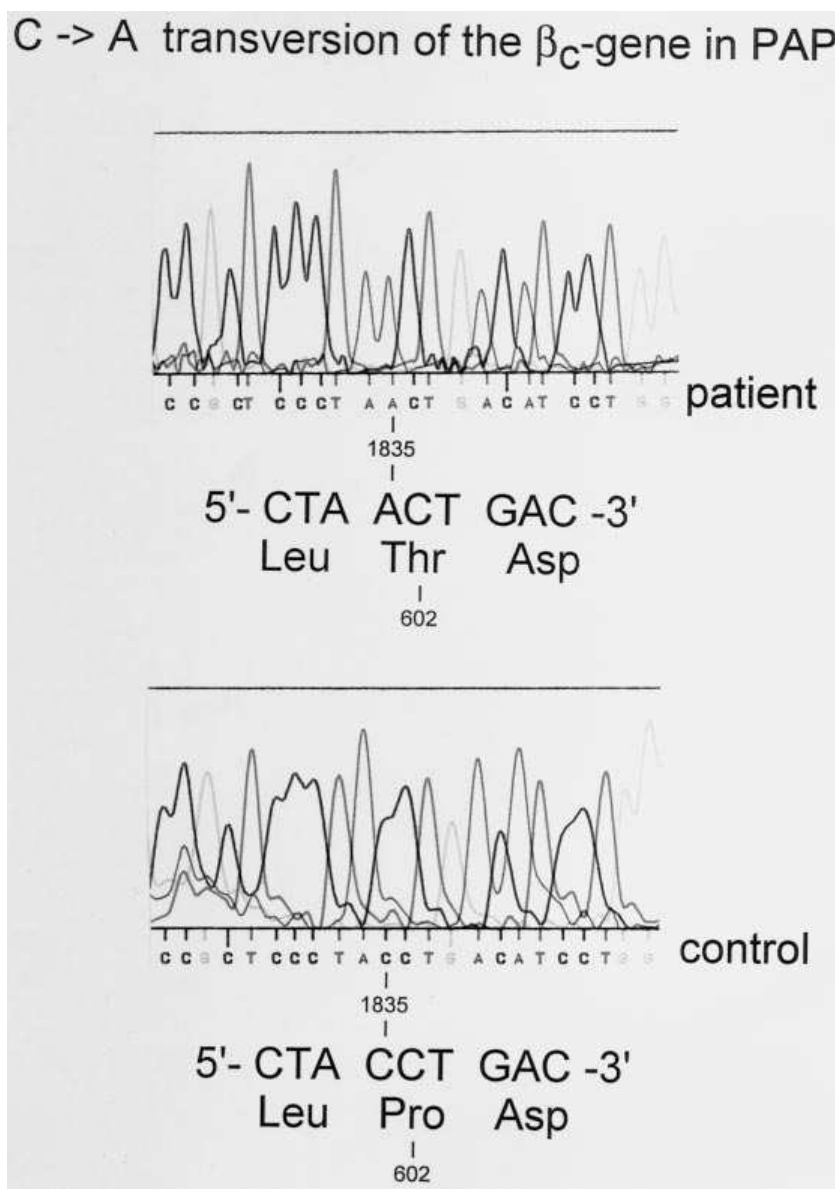

Figure 3. Patient and wild-type DNA sequence demonstrating the CCT (Pro) to ACT (Thr) mutation in codon 602 of the genomic $\beta c$ DNA.

netic etiology. Based on available data, some cases of congenital PAP can be attributed to absent or deficient SP-B production $(1,17)$ predominantly due to the 121 ins 2 mutation $(2,4)$. However, most pediatric patients presented to date with PAP cannot be allocated to either of these groups. Thus, the molecular mechanism in PAP patients without the common SP-B mutation remains to be elucidated.

The human GM-CSF, IL-3, and IL-5 receptors consist of the $\beta c$ chain and a private $\alpha$ chain. The $\alpha / \beta c$ heterodimer binds its ligand with high affinity, whereas $\alpha$ monomers bind their ligand with low affinity (18).

Analysis of patients' PBMCs with $\beta \mathrm{c}, \mathrm{GM}-\mathrm{CSF}-\mathrm{R} \alpha$, and IL-3-R $\alpha$ specific antibodies revealed a striking reduction solely of $\beta c$. The antibody binding data were confirmed by ${ }^{125} \mathrm{I}-\mathrm{GM}-$ CSF binding studies and Scatchard analysis. In these studies, patients' cells bound GM-CSF with low affinity, indicating the normal presence of the private $\alpha$ chain but not of $\beta c$. For further characterization of the functional consequences of $\beta c$ absence, we examined clonogenic growth of the patients' hematopoietic progenitor cells in response to growth factors. We used GM-CSF and IL-3 functioning through binding to receptors containing $\beta c$ and other stimuli (G-CSF, IL-6, and SCF) functioning independent from $\beta \mathrm{c}$. GM-CSF and IL-3 had almost no effect on clonogenic growth of the patients' progenitor cells, whereas growth in response to G-CSF or IL-6 and
SCF was normal. Thus, the pattern of clonogenic growth provides additional proof for the reduction of the $\beta c$ chain.

Next, we looked at putative mutations that might cause the $\beta c$ defect. The presence of $\beta c$ mRNA was demonstrated by RT-PCR. Analysis of PCR-derived cDNA clones revealed a C to A transversion at codon 602 which causes a substitution of wild-type proline to mutant threonine in the DNA sense strand in one patient. This mutation was present in all clones. The sequences of 20 randomly selected healthy controls showed no polymorphism in this codon. The $\beta c$ DNA did not differ otherwise from published sequences. The codon 602 is an intra- and interspecies conserved amino acid region among the cytokine receptor family, indicating that this motif might be important for the integrity of the $\beta c$ protein. Moreover, proline is an exceptional amino acid, in which the nitrogen atom of the amino group is incorporated into a ring structure. One important reason for the variation of the regular secondary structure arrangement of $\alpha$-helices and $\beta$-sheets is the presence of the amino acid proline. This unique structure confers an angular deviation of the helical structure as a consequence of the interrupted regular hydrogen binding. The analysis of the $\beta c$ mutant protein structure shows that the exchange of proline due to the point mutation in the $\beta \mathrm{c}$ gene could lead to a change in the $\beta \mathrm{c}$ protein structure.

Our data suggest that human PAP can be associated with a defect of $\beta c$ expression. Independent evidence for this concept has been provided by Nishinakamura et al. in gene targeting experiments (11). Targeted disruption of $\beta c$ mouse embryonic stem cells yields the phenotype of PAP with a histology indistinguishable from that seen in our patients. The role of $\beta c$ in the pathogenesis of human PAP remains to be clarified. $\beta \mathrm{c}$ is predominantly expressed on cells of the myeloid lineage (19) which differentiate in the lung into alveolar macrophages. Recent results indicate that $\operatorname{GM}-\operatorname{CSF}(9,20)$ and the alveolar macrophages $(21,22)$ play an important role in the catabolism and clearance of SPs. The alveolar macrophages in human PAP (23) and $\beta c$ knockout mice (11) appear foamy and are loaded with proteinaceous material. The alveolar macrophages appear to incorporate the surfactant, are incapable of processing it, and become enlarged and immobile. The concept that an abnormal alveolar macrophage function is associated with PAP has been described (24-26). In the context of these observations, one is tempted to postulate that $\beta \mathrm{c}$ deficiency may contribute to some variance within the wide range of PAP forms. It is clear from this study that congenital and infantile PAP is associated with a defect in $\beta c$ expression, at least in some cases. We have demonstrated recently that bone marrow transplantation from wild-type to $\beta c$ mutant mice and subsequent macrophage engraftment into the lung leads to reversal of PAP (27). Furthermore, we analyzed a group of pediatric acute myeloid leukemia patients with PAP, lacking the $\beta \mathrm{c}$ chain on their myeloid blasts. In these patients we could demonstrate that elimination of $\beta c$ clone by high-dose chemotherapy and autologous or allogeneic expansion of $\beta c$-positive cells were associated with a significant regression of PAP symptoms (28). These data provide additional evidence of alveolar macrophage involvement in the disease.

\section{Acknowledgments}

We thank William M. Hull, Jeffrey A. Whitsett, Matthias Griese, and Paul Stevens for performing the SP-B and SP-A ELISAs; Aaron 
Hamvas, Phil Ballard, Peter Birrer, Heinz Hubrich, Georg Kluitmann, Anastassios Koumbourlis, Horst Schroten, and Asher Tal for providing patient samples during the diagnostic work up; and Toshio Kitamura for constructive and helpful discussions.

This work was supported by the Deutsche Forschungsgemeinschaft, Sonderforschungsbereich 503, the BMBF BioRegio Program (Proj. 11661), the Dr. Mildred Scheel Stiftung der Deutschen Krebshilfe (W11/94/Bu2, Project No. 10361), and the Elterninitiative Kinderkrebsklinik Düsseldorf e.V.

\section{References}

1. Nogee, L.M., D.E. deMello, L.P. Dehner, and H.R. Colten. 1993. Brief report: deficiency of pulmonary surfactant protein $\mathrm{B}$ in congenital alveolar proteinosis. N. Engl. J. Med. 328:406-410.

2. Nogee, L.M., G. Garnier, H.C. Dietz, L. Singer, A.M. Murphy, D.E. deMello, and H.R. Colten. 1994. A mutation in the surfactant protein B gene responsible for fatal neonatal respiratory disease in multiple kindreds. J. Clin. Invest. $93: 1860-1863$.

3. Schumacher, R.E., A.J. Marrogi, and K.P. Heidelberger. 1989. Pulmonary alveolar proteinosis in a newborn. Pediatr. Pulmonol. 7:178-182.

4. deMello, D.E., L.M. Nogee, S. Heyman, H.F. Krous, M. Hussain, T.A. Merritt, W. Hsueh, J.E. Haas, K. Heidelberger, R. Schumacher, et al. 1994. Molecular and phenotypic variability in the congenital alveolar proteinosis syndrome associated with inherited surfactant protein B deficiency. J. Pediatr. 125: $43-50$.

5. Moulton, S.L., H.F. Krous, T.A. Merritt, R.M. Odell, E. Gangitano, and J.D. Cornish. 1992. Congenital pulmonary alveolar proteinosis: failure of treatment with extracorporeal life support [see comments]. J. Pediatr. 120:297-302.

6. Wasserman, K., and G.R. Mason. 1994. Pulmonary alveolar proteinosis. In Textbook of Respiratory Medicine. J.F. Murray and J.A. Nadel, editors. W.B. Saunders Co., Philadelphia. 1933-1946.

7. Spock, A. 1993. Treatment of congenital alveolar proteinosis [letter; comment]. J. Pediatr. 123:495-496.

8. Mahut, B., J. de-Blic, M. Le-Bourgeois, A. Beringer, J.Y. Chevalier, and P. Scheinmann. 1992. Partial and massive lung lavages in an infant with severe pulmonary alveolar proteinosis. Pediatr. Pulmonol. 13:50-53.

9. Dranoff, G., A.D. Crawford, M. Sadelain, B. Ream, A. Rashid, R.T. Bronson, G.R. Dickersin, C.J. Bachurski, E.L. Mark, J.A. Whitsett, et al. 1994. Involvement of granulocyte-macrophage colony-stimulating factor in pulmonary homeostasis. Science (Wash. DC). 264:713-716.

10. Stanley, E., G.J. Lieschke, D. Grail, D. Metcalf, G. Hodgson, J.A. Gall, D.W. Maher, J. Cebon, V. Sinickas, and A.R. Dunn. 1994. Granulocyte/macrophage colony-stimulating factor-deficient mice show no major perturbation of hematopoiesis but develop a characteristic pulmonary pathology. Proc. Natl. Acad. Sci. USA. 91:5592-5596.

11. Nishinakamura, R., N. Nakayama, Y. Hirabayashi, T. Inoue, D. Aud, T. McNeil, S. Azuma, S. Yoshida, Y. Toyoda, K. Arai, et al. 1995. Mice deficient for the IL-3/GM-CSF/IL-5 beta c receptor exhibit lung pathology and impaired immune response, while beta IL-3 receptor-deficient mice are normal. Immunity. 2:211-222.
12. Kramer, H.J., R. Schmidt, A. Gunther, G. Becker, Y. Suzuki, and W. Seeger. 1995. ELISA technique for quantification of surfactant protein B (SP-B) in bronchoalveolar lavage fluid. Am. J. Respir. Crit. Care Med. 152:1540-1544.

13. Burdach, S., N. Zessack, D. Dilloo, M. Shatsky, D. Thompson, and L. Levitt. 1991. Differential regulation of lymphokine production by distinct subunits of the T cell interleukin 2 receptor. J. Clin. Invest. 87:2114-2121.

14. Dilloo, D., U. Dirksen, N. Zessack, B. Buttlies, L. Levitt, and S. Burdach. 1996. Differential production of interleukin-3 in human T lymphocytes following either CD3 or CD2 receptor activation. Exp. Hematol. 24:537-543.

15. Aymard, J.P., M. Gyger, R. Lavallee, L.P. Legresley, and M. Desy. 1984 A case of pulmonary alveolar proteinosis complicating chronic myelogenous leukemia. A peculiar pathologic aspect of busulfan lung? Cancer. 53:954-956.

16. Green, D., P. Dighe, N.O. Ali, and G.V. Katele. 1980. Pulmonary alveolar proteinosis complicating chronic myelogenous leukemia. Cancer. 46:17631766.

17. Hamvas, A., F.S. Cole, D.E. deMello, M. Moxley, J.A. Whitsett, H.R Colten, and L.M. Nogee. 1994. Surfactant protein B deficiency: antenatal diagnosis and prospective treatment with surfactant replacement. J. Pediatr. 125: 356-361.

18. Callard, R., and A. Gearing. 1994. The Cytokine Facts Book. Academic Press, San Diego. 265 pp.

19. Wognum, A.W., Y. Westerman, T.P. Visser, and G. Wagemaker. 1994. Distribution of receptors for granulocyte-macrophage colony-stimulating factor on immature $\mathrm{CD} 34+$ bone marrow cells, differentiating monomyeloid progenitors, and mature blood cell subsets. Blood. 84:764-774.

20. Huffman, J.A., W.M. Hull, G. Dranoff, R.C. Mulligan, and J.A. Whitsett. 1996. Pulmonary epithelial cell expression of GM-CSF corrects the alveolar proteinosis in GM-CSF-deficient mice. J. Clin. Invest. 97:649-655.

21. Wright, J.R., and D.C. Youmans. 1995. Degradation of surfactant lipids and surfactant protein A by alveolar macrophages in vitro. Am. J. Physiol. 268: L772-L780.

22. Miyamura, K., L.E. Leigh, J. Lu, J. Hopkin, A. Lopez-Bernal, and K.B. Reid. 1994. Surfactant protein D binding to alveolar macrophages. Biochem. J. 300:237-242.

23. Hamvas, A., L.M. Nogee, D.E. deMello, and F.S. Cole. 1995. Pathophysiology and treatment of surfactant protein-B deficiency. Biol. Neonate. 67(Suppl. 1):18-31.

24. Golde, D.W., M. Territo, T.N. Finley, and M.J. Cline. 1976. Defective lung macrophages in pulmonary alveolar proteinosis. Ann. Intern. Med. 85:304309 .

25. Harris, J.O. 1979. Pulmonary alveolar proteinosis: abnormal in vitro function of alveolar macrophages. Chest. 76:156-159.

26. Nugent, K.M., and E.L. Pesanti. 1983. Macrophage function in pulmonary alveolar proteinosis. Am. Rev. Respir. Dis. 127:780-781.

27. Nishinakamura, R., R. Wiler, U. Dirksen, Y. Morikawa, A. Ken-ichi, A. Miyajima, S. Burdach, and R. Murray. 1996. The pulmonary alveolar proteinosis in granulocyte macrophage colony-stimulating factor/interleukins $3 / 5 \beta \mathrm{c}$ receptor-deficient mice is reversed by bone marrow transplantation. J. Exp. Med. 183:2657-2662.

28. Dirksen, U., R. Nishinakamura, R. Murray, and S. Burdach. 1996. Defective GM-CSF/IL-3/IL-5 receptor common $\beta$ chain expression associated with human pulmonary alveolar proteinosis with or without AML and its correction by hematopoietic stem cell transplantation. Blood. 88(Suppl. 1):660a. 